\title{
Peran modul mp-asi dalam perilaku pemberian mp-asi pada ibu anak bawah dua tahun (baduta)
}

\author{
Sri Hapsari SP', Ani Margawati ${ }^{2}$, SA. Nugraheni ${ }^{3}$
}

\begin{abstract}
Background : Lack of complementary feeding behavior is one of the problems in Indonesia. Nutrition education about complementary feeding among mother from infants aged 6-24 months should be carried out to support compelementary feeding behavior. Module with an easily language punctuated by images and can be learned at home is expected to incerase complementary feeding behavior among mothers from child under two years old.

Method: The design of this research was quasi-experimental with non-randomized pre-test and post-test control group design. Training of complementary feedings module were given for four meetings. The annalyze were conducted by SPSS program.

Result : This study found that the median age of subjects between two group are adults. The median duration of education are 9 years. There was no difference of Financial families outcome in the both of groups is low. Nutrition education with module can increase complementary feeding behavior at intervention group and the improvement of this scores better than control group. Complementary feeding behavior retention increased significant among 2 weeks and 1 month after intervention.

Conclusion : Nutrition education with module contribute to improve complementary feeding behavior among mothers from child under two years old.
\end{abstract}

Key words : nutrition education, complementary feeding behavior, complementary feedings modul

\begin{abstract}
ABSTRAK
Latar Belakang : Perilaku pemberian MP-ASI yang salah masih menjadi salah satu masalah di Indonesia. Pendidikan gizi mengenai pemberian MP-ASI yang benar pada ibu bayi usia

6-24 bulan perlu dilakukan guna mendukung pemberian MP-ASI. Pendidikan gizi menggunakan modul dengan bahasa yang diperjelas dengan gambar dan bisa dipelajari di rumah diharapkan dapat meningkatan perilaku pemberian pada ibu anak baduta.

Metode : Rancangan penelitian ini adalah Quasi Experiment with non randomized pre post-test control group design. Subjek diambil secara purposive sampling, dengan jumlah subjek adalah 24 ibu untuk setiap kelompok. Pelatihan modul MP-ASI diberikan dalam 4 kali pertemuan. Analisis statistik yang digunakan adalah Independent Samples T-Test, Mann Whitney, Paired T Test dan Wilcoxon.

Hasil : Penelitian ini menemukan bahwa nilai tengah usia subjek pada kedua kelompok termasuk golongan usia dewasa. Nilai tengah pendidikan subjek pada kelompok perlakuan maupun kelompok kontrol sama yaitu 9 tahun. Pengeluaran perkapita keluarga pada kelompok perlakuan maupun kontrol tergolong rendah. Pendidikan gizi menggunakan modul MP-ASI berperan dalam meningkatkan perilaku pemberian MP-ASI pada ibu kelompok perlakuan, dan perubahan skornya lebih tinggi dibanding kelompok kontrol. Retensi perilaku mengalami peningkatan bermakna pada 2 minggu dan 1 bulan setelah perlakuan.

Simpulan : Pendidikan gizi menggunakan modul MP-ASI berperan dalam meningkatkan perilaku pemberian MP-ASI pada ibu anak baduta.
\end{abstract}

\section{PENDAHULUAN}

Pemberian air susu ibu (ASI) saja tanpa tambahan makanan atau minuman lainnya perlu dilakukan kepada bayi sejak lahir sampai berusia 6 bulan setelah itu bayi perlu diberi makanan pendamping ASI (MPASI). ${ }^{1}$ Pemberian ASI dan MP-ASI yang benar pada usia bayi dapat menurunkan angka kematian bayi sampai $19 \%$ dan mencegah terjadinya masalah gizi

\footnotetext{
1. Program Studi Ilmu Gizi Sekolah Tinggi Ilmu Kesehatan Widya Cipta Husada, Malang (email korespondensi: sri.hapsari11@gmail.com)

2. Departemen Ilmu Gizi, Fakultas Kedokteran Universitas Diponegoro, Semarang

3. Prodi Magister Ilmu Kesehatan Masyarakat, Fakultas Kesehatan Masyarakat Universitas Diponegoro, Semarang
}

terutama di negara berkembang. ${ }^{2}$ Pemberian MP-ASI yang salah akan berpengaruh signifikan terhadap pertumbuhan dan perkembangan anak dengan terjadinya penyimpangan pertambahan berat badan yang cenderung menurun. ${ }^{3}$

Studi multisenter tentang MP-ASI menunjukkan bahwa MP-ASI yang diberikan pada anak baduta masih dibawah AKG, terutama masalah rendahnya mikronutrien pada MP-ASI tradisional yang hanya memenuhi 20\% AKG. ${ }^{4}$ Hasil Riset Kesehatan Dasar (Riskesdas) pada tahun 2010 juga menunjukkan bahwa terdapat $34,7 \%$ anak usia $6-11$ bulan dan $30,4 \%$ anak usia $12-23$ bulan yang berstatus gizi kurus, sangat kurus dan lebih. Angka tersebut lebih tinggi dibanding status gizi kurus, sangat kurus, dan lebih pada usia kurang dari 6 bulan maupun usia setelah 23 bulan. ${ }^{5}$ 
Angka kematian balita di kota Semarang masih tinggi, yaitu sebesar 0,27\% pada tahun 2011. Salah satu penyebab kematian balita karena masalah gizi. Kota Semarang merupakan daerah rawan gizi ditunjukkan dengan masih adanya $1,61 \%$ kasus balita gizi buruk pada tahun 2011. ${ }^{6}$ Puskesmas Bangetayu merupakan puskesmas di kota Semarang dengan angka status gizi buruk tinggi yaitu 5,2\%. ${ }^{7}$ Praktik pemberian MP-ASI yang terlalu dini juga terjadi di Puskesmas Bangetayu. Berdasar laporan Puskesmas Bangetayu pada bulan September 2012, diketahui bahwa 95\% bayi sudah mendapat MP-ASI sebelum usia 6 bulan. ${ }^{8}$

Pengetahuan dan pengalaman yang dimiliki ibu berhubungan dengan pemberian MP-ASI yang benar. Ibu yang memiliki pengetahuan yang kurang mengenai MP-ASI akan merasa kurang yakin bahwa dengan pemberian MP-ASI tidak akan mencukupi kebutuhan bayi. Hasil survei pendahuluan yang dilakukan di Puskesmas Bangetayu, menunjukkan bahwa tidak ada ibu yang mempunyai pengetahuan baik mengenai MPASI. Promosi mengenai pemberian MP-ASI yang benar pada ibu bayi usia $6-24$ bulan perlu dilakukan guna mendukung pemberian MP-ASI. ${ }^{9}$

Perubahan perilaku didasari dengan adanya perubahan atau penambahan pengetahuan, sikap, atau ketrampilannya. Faktor yang berpengaruh terhadap keberhasilan suatu pendidikan adalah pemilihan metode dengan media yang tepat. ${ }^{10}$ Menurut Departemen Kesehatan, untuk mengubah pengetahuan dapat digunakan metode ceramah, tugas baca, panel, dan konseling, sedangkan untuk mengubah sikap dapat digunakan metode curah pendapat, diskusi kelompok, tanya jawab, dan pameran. ${ }^{10}$

Modul sebagai sistem pengorganisasian proses pendidikan yang disusun sedemikian rupa sehingga peserta dapat belajar secara sistematis untuk mencapai tujuan yang diinginkan. ${ }^{11}$ Modul MP-ASI dengan bahasa yang mudah dipahami, diperjelas dengan gambar, foto dan bisa dipelajari di rumah diharapkan dapat meningkatan pengetahuan dan sikap yang nantinya dapat merubah perilaku pemberian makan.

\section{BAHAN DAN METODE}

Penelitian yang dilakukan termasuk penelitian quasi experimental, dengan rancangan non randomized pre-test and post-test control group. ${ }^{12}$ Perlakuan yang diberikan adalah pendidikan gizi menggunakan modul MP-ASI. Pendidikan gizi dengan media modul MPASI diberikan pada kelompok perlakuan setelah pretest, sedangkan pada kelompok kontrol diberi pendidikan gizi dengan media buku KIA. Kelompok perlakuan terletak di kelurahan Bangetayu Kulon dimana angka masalah gizinya masih tinggi.

K,elurahan Kudu sebagai kelompok kontrol letaknya terpisahkan dua kelurahan dan jalan raya dari kelurahan Bangetayu Kulon. Diharapkan tidak terjadi saling memberikan informasi mengenai MP-ASI dengan adanya jarak yang jauh antara kelompok perlakuan dan kontrol. Jumlah subjek berdasar perhitungan yaitu 24 ibu untuk setiap kelompok. ${ }^{13}$ Penentuan subjek penelitian menggunakan purposive sampling dengan kriteria ibu mempunyai anak usia $6-$ 20 bulan, tidak bekerja, dan bersedia menjadi subjek penelitian.

Pendidikan gizi yang dilaksanakan menggunakan metode ceramah, diskusi dan demonstrasi. Modul sebagai media pendidikan gizi dibuat dalam bentuk buku dengan bahasa yang mudah dipahami dan diperjelas dengan gambar. Penyusunan modul berdasar hasil survei pendahuluan terhadap masalah yang dihadapi ibu dalam memberikan MP-ASI. ${ }^{14,15}$ Perilaku pemberian MP-ASI diketahui melalui kuesioner dan dicek dengan lembar tilik. Usia pemberian MP-ASI, bentuk MP-ASI yang pertama kali diberikan, pemberian ASI disaat ini, persiapan sebelum memberikan MP-ASI, cara memberikan MP-ASI, konsumsi camilan, macam, porsi, frekuensi, dan bentuk MP-ASI yang dikonsumsi merupakan perilaku pemberian MP-ASI yang diamati.

Instrumen yang digunakan dalam penelitian ini telah diuji validitas dan realiabilitasnya. Modul sebagai media pendidikan gizi juga sudah diujicobakan dengan metode Focus Group Discussion (FGD). Uji coba modul dan kuesioner dilaksanakan pada ibu anak baduta di wilayah kerja Puskesmas Genuk yang memiliki karakteristik sama dengan lokasi penelitian. Pendidikan gizi menggunakan modul MP-ASI dilaksanakan selama 4 kali pertemuan disampaikan oleh peneliti. Pengisian kuesioner perilaku MP-ASI pada kelompok perlakuan dilakukan sebelum pemberian pendidikan gizi, dan pengukuran post-test dilaksanakan setelah perlakuan. Observasi perilaku MP-ASI dilaksanakan sehari sebelum dan sehari setelah perlakuan. Pelaksanaan pre-test, post-test dan observasi perilaku MP-ASI pada kelompok kontrol dilakukan bersamaan dengan pelaksanaan pre-test, post-test dan observasi pada kelompok perlakuan untuk menghindari bias.

Analisis data dilakukan secara statistik dengan bantuan program SPSS. Analisis univariat dilakukan untuk mendeskripsikan data karakteristik subjek. Analisis bivariat menggunakan Independent Samples T-Test, Mann Whitney, Paired T Test dan Wilcoxon. Uji normalitas dilakukan sebelum pelaksanaan analisis bivariat untuk menentukan uji statistik yang digunakan. ${ }^{16}$

\section{HASIL}

Subjek penelitian adalah ibu dari anak yang berusia $6-20$ bulan, tidak bekerja dan tinggal di wilayah kerja 
Puskesmas Bangetayu, Semarang. Jumlah subjek pada masing - masing kelompok perlakuan dan kontrol adalah 24 ibu. Hasil penelitian menunjukkan bahwa nilai tengah usia subjek pada kelompok perlakuan termasuk golongan usia dewasa yaitu 29 tahun pada kelompok perlakuan dan 24 tahun pada kelompok kontrol. Nilai tengah pendidikan subjek pada kelompok perlakuan maupun kelompok kontrol sama yaitu 9 tahun atau setara dengan SMP. Pengeluaran perkapita keluarga pada kelompok perlakuan maupun kontrol tergolong rendah sesuai tabel 1.

Tabel 1. Distribusi karakteristik subjek pada kelompok perlakuan dan kontrol

\begin{tabular}{|c|c|c|c|c|c|c|c|}
\hline \multirow{2}{*}{$\begin{array}{c}\text { Karakteristik } \\
\text { Subjek }\end{array}$} & \multicolumn{3}{|c|}{ Perlakuan $(n=24)$} & \multicolumn{3}{|c|}{ Kontrol $(n=24)$} & \multirow[t]{2}{*}{$\boldsymbol{P}$} \\
\hline & $\begin{array}{c}\text { Mi } \\
\text { n }\end{array}$ & Max & $\begin{array}{c}\text { Mean/ } \\
\text { Median } \pm \text { SD }\end{array}$ & $\begin{array}{c}\text { Mi } \\
\text { n }\end{array}$ & Max & $\begin{array}{c}\text { Mean/ } \\
\text { Median } \pm \text { SD }\end{array}$ & \\
\hline Usia ibu (tahun) & 20 & 40 & $28,5 \pm 4,88^{a}$ & 19 & 40 & $24,0 \pm 6,35^{\mathrm{a}}$ & $0,142^{\mathrm{c}}$ \\
\hline Usia anak (bulan) & 7 & 19 & $11,5 \pm 4,45^{\mathrm{a}}$ & 7 & 19 & $14,0 \pm 4,01^{\mathrm{a}}$ & $0,717^{\mathrm{c}}$ \\
\hline Pendidikan ibu (tahun) & 3 & 12 & $9,0 \pm 2,55^{\mathrm{a}}$ & 6 & 12 & $9,0 \pm 2,34^{\mathrm{a}}$ & $0,108^{c}$ \\
\hline Pengeluaran keluarga (per seribu rupiah) & 150 & 375 & $250 \pm 71,16^{\mathrm{a}}$ & 166 & 375 & $212,5 \pm 55,28^{\mathrm{a}}$ & $0,104^{\mathrm{c}}$ \\
\hline Informasi MP-ASI dari media lain & 0,0 & 4,0 & $0,0 \pm 1,4^{\mathrm{a}}$ & 0,0 & 4,0 & $1,0 \pm 1,41^{\mathrm{a}}$ & $0,121^{\mathrm{c}}$ \\
\hline Sikap keluarga $(\%)$ & 37,5 & 87,5 & $62,5 \pm 15,19^{a}$ & 50,0 & 87,5 & $62,5 \pm 11,6^{\mathrm{a}}$ & $0,571^{\mathrm{c}}$ \\
\hline Pengetahuan MP-ASI pre-test $(\%)$ & 23,8 & 76,2 & $48,0 \pm 13,17^{\mathrm{b}}$ & 19,0 & 71,4 & $46,6 \pm 14,99^{b}$ & $0,735^{\mathrm{d}}$ \\
\hline Sikap MP-ASI pre-test $(\%)$ & 30,0 & 90,0 & $64,6 \pm 16,68^{b}$ & 40,0 & 90,0 & $70,4 \pm 12,33^{b}$ & $0,175^{\mathrm{d}}$ \\
\hline Praktik MP-ASI pre-test $(\%) /$ & 20,0 & 60,0 & $50,0 \pm 10,42^{\mathrm{a}}$ & 20,0 & 60,0 & $40,0 \pm 13,41^{\mathrm{a}}$ & $0,865^{\mathrm{c}}$ \\
\hline
\end{tabular}

Kondisi awal subjek antara kelompok perlakuan dan kelompok kontrol perlu dibandingkan untuk mengetahui homogenitas subjek antara kedua kelompok. Tabel distribusi karakteristik subjek menunjukkan bahwa tidak ada perbedaan usia, pendidikan, pengeluaran perkapita keluarga, informasi dari media lain, sikap keluarga, pengetahuan, sikap, dan praktik MP-ASI saat pre-test antara kelompok perlakuan dan kelompok kontrol $(p>0,05)$. Homogenitas antara kedua kelompok menunjukkan bahwa variabel perancu dapat dikendalikan.

\section{Deskripsi Perilaku MP-ASI Sebelum dan Setelah Perlakuan pada Kelompok Perlakuan}

Deskripsi perilaku MP-ASI merupakan persentase jawaban benar dari masing-masing item pertanyaan perilaku MP-ASI pada kelompok perlakuan dan kelompok kontrol. Persentase jawaban benar tersebut dilihat pada saat sebelum dan setelah perlakuan. Sebanyak $8,33 \%$ subjek pada kelompok perlakuan yang memberikan MP-ASI pertama kali pada usia 6 bulan dan 4,17\% memberikan MP-ASI pertamakali dalam bentuk semi cair. Sebagian besar subjek yaitu 91,7\% yang masih memberikan ASI sampai sekarang. Penurunan persentase jawaban terjadi pada kuesioner perilaku setelah diberi pendidikan gizi dengan modul MP-ASI yaitu pada item macam MP-ASI yang dikonsumsi sesuai dengan Tabel 2.

Tabel 2.Persentase jawaban benar perilaku MP-ASI pada kelompok perlakuan

\begin{tabular}{lcccc}
\hline \multicolumn{1}{c}{ Item } & \multicolumn{2}{c}{ Pre-test $(\mathbf{n = 2 4})$} & \multicolumn{2}{c}{ Post-test $(\mathbf{n = 2 4})$} \\
\cline { 2 - 5 } & $\mathbf{F}$ & $\mathbf{\%}$ & $\mathbf{F}$ & $\mathbf{\%}$ \\
\hline PERILAKU & & & & 8,3 \\
Usia pemberian MP-ASI & 2 & 8,3 & 2 & 4,2 \\
Bentuk MP-ASI pertama kali & 1 & 4,2 & 1 & 91,7 \\
Pemberian ASI disaat ini & 22 & 91,7 & 22 & 45,8 \\
Persiapan sebelum memberikan MP-ASI & 4 & 16,7 & 11 & 66,7 \\
Cara memberikan MP-ASI & 9 & 37,5 & 16 & 8,3 \\
Macam MP-ASI yang dikonsumsi & 3 & 12,5 & 2 & 75,0 \\
Porsi MP-ASI yang dikonsumsi & 18 & 75,0 & 18 & 87,5 \\
Bentuk MP-ASI yang dikonsumsi & 13 & 54,2 & 21 & 95,8 \\
Konsumsi camilan oleh anak ibu & 19 & 79,2 & 23 & 79,2 \\
Frekuensi pemberian MP-ASI & 12 & 50,0 & 19 & \\
\hline
\end{tabular}

\section{Deskripsi Perilaku MP-ASI Sebelum dan Setelah Perlakuan pada Kelompok Kontrol}

Sebagian besar item pertanyaan perilaku MP-ASI post-test pada kelompok kontrol mengalami peningkatan jawaban. Penurunan persentase jawaban item perilaku terjadi saat post-test yaitu pada item macam MP-ASI yang dikonsumsi. Seluruh subjek telah memberikan MP-ASI pertama kali pada anak sebelum 
usia 6 bulan. Sebanyak 12,5\% subjek memberikan MPASI pertama kali dalam bentuk semi cair. Hampir seluruh subjek yaitu $83,33 \%$ yang masih memberikan
ASI sampai sekarang. Uraian persentase perilaku MPASI pre-test dan post-test pada kelompok kontrol disajikan pada Tabel 3.

Tabel 3. Persentase jawaban benar perilaku pada kelompok kontrol

\begin{tabular}{lcccc}
\hline \multicolumn{1}{c}{ Item } & \multicolumn{2}{c}{ Pre-test $(\mathbf{n = 2 4 )}$} & \multicolumn{2}{c}{ Post-test $(\mathbf{n = 2 4})$} \\
\cline { 2 - 5 } PERILAKU & F & \% & F & \\
Usia pemberian MP-ASI & & & & 0 \\
Bentuk MP-ASI pertama kali & 0 & 0 & 3 & 12,50 \\
Pemberian ASI disaat ini & 3 & 12,50 & 20 & 83,33 \\
Persiapan sebelum memberikan MP-ASI & 20 & 83,33 & 11 & 45,80 \\
Cara memberikan MP-ASI & 9 & 37,50 & 16 & 66,70 \\
Macam MP-ASI yang dikonsumsi & 6 & 25,00 & 2 & 8,33 \\
Porsi MP-ASI yang dikonsumsi & 3 & 12,50 & 18 & 75,00 \\
Bentuk MP-ASI yang dikonsumsi & 10 & 41,67 & 21 & 87,50 \\
Konsumsi camilan oleh anak ibu & 19 & 79,17 & 23 & 95,80 \\
Frekuensi pemberian MP-ASI & 19 & 79,17 & 19 & 79,20 \\
\hline
\end{tabular}

Pengaruh Pendidikan Gizi Menggunakan Modul MP-ASI terhadap Perilaku MP-ASI pada Kelompok Perlakuan dibanding Kelompok Kontrol

Tabel 4 menunjukkan bahwa terjadi peningkatan skor perilaku pemberian MP-ASI pada kelompok perlakuan setelah diberi pendidikan gizi menggunakan modul MP-ASI. Pendidikan gizi menggunakan modul
MP-ASI secara statistik bermakna dalam meningkatkan skor perilaku MP-ASI pada kelompok perlakuan $(p<0,05)$. Peningkatan skor perilaku MPASI juga terjdi pada kelompok kontrol saat post-test. Perubahan skor post-test perilaku MP-ASI pada kelompok kontrol secara statistik tidak bermakna $(p>$ $0,05)$ sesuai tabel 4.

Tabel 4. Skor perilaku MP-ASI sebelum dan setelah perlakuan pada kelompok perlakuan dan kontrol

\begin{tabular}{lcc}
\hline \multicolumn{1}{c}{ Variabel } & Perlakuan $(\mathbf{n}=\mathbf{2 4})$ & Kontrol $(\mathbf{n}=\mathbf{2 4})$ \\
\hline Perilaku MP-ASI pre-test $(\%)$ & $50,0 \pm 10,42^{\mathrm{a}}$ & $40,0 \pm 13,41^{\mathrm{b}}$ \\
Perilaku MP-ASI post-test $(\%)$ & $60,0 \pm 8,24^{\mathrm{a}}$ & $45,0 \pm 12,16^{\mathrm{a}}$ \\
$P$ & $0,000^{\mathrm{d}^{*}}$ & $0,061^{\mathrm{c}}$ \\
\hline $\mathrm{a}:$ Median $\pm S D$ & $\mathrm{~b}:$ Mean $\pm S D$ & $\mathrm{c}:$ Wilcoxon test $\alpha=0,05$ \\
$\mathrm{~d}:$ Paired Samples T-test $, \alpha=0,05$ & & $*:$ sangat bermakna $(p<0,05)$
\end{tabular}

Tabel 5. Perubahan skor perilaku MP-ASI pada kelompok perlakuan dan kontrol

\begin{tabular}{lccc}
\multicolumn{1}{c}{ Variabel } & $\begin{array}{c}\text { Perlakuan } \\
(\mathrm{n}=24)\end{array}$ & $\begin{array}{c}\text { Kontrol } \\
(\mathrm{n}=24)\end{array}$ & $P$ \\
\hline $\begin{array}{l}\text { Perubahan Skor Pre-test dan Post-test } \\
\Delta \text { Perilaku MP-ASI }(\%)\end{array}$ & $10,0 \pm 12,74^{\mathrm{a}}$ & $5,0 \pm 13,18^{\mathrm{a}}$ & $0,027^{\mathrm{b}^{*}}$ \\
\hline $\mathrm{a}:$ Median $\pm S D$ & $\mathrm{~b}:$ Mann Whitney, $\alpha=0,05$ & $*:$ sangat bermakna $(p<0,05)$
\end{tabular}

Tabel 5 menunjukkan adanya kenaikan skor perilaku MP-ASI pada kelompok perlakuan setelah diberi pendidikan gizi menggunakan modul MP-ASI. Peningkatan skor perilaku MP-ASI juga terjadi pada kelompok kontrol. Pendidikan gizi menggunakan modul MP-ASI secara statistik bermakna $(\mathrm{p}<0,05)$ dalam meningkatkan perilaku MP-ASI pada kelompok perlakuan dan perubahannya jauh lebih besar dibanding kelompok kontrol.

\section{Retensi Perilaku MP-ASI}

Pengukuran retensi dilakukan untuk melihat berapa lama modul MP-ASI dapat merubah perilaku MP-ASI. Retensi perilaku MP-ASI diukur saat 2 minggu dan 1 bulan pada kelompok perlakuan setelah diberi pendidikan gizi menggunakan modul MP-ASI. Perubahan skor perilaku MP-ASI mengalami peningkatan pada 2 minggu dan 1 bulan setelah diberi pendidikan gizi menggunakan modul MP-ASI. Peningkatan skor perilaku MP-ASI pada 2 minggu maupun 1 bulan setelah perlakuan secara statistik bermakna $(p<0,05)$ sesuai tabel 6 . 
Tabel 6. Skor perilaku 2 minggu dan 1 bulan setelah perlakuan pada kelompok perlakuan

\begin{tabular}{cccccc}
\hline Variabel & $\begin{array}{c}\text { Setelah } \\
\text { Perlakuan } \\
(\mathbf{n = 2 4})\end{array}$ & $\begin{array}{c}\mathbf{2} \text { Minggu } \\
(\mathbf{n = 2 4 )}\end{array}$ & $\boldsymbol{P}$ & $\begin{array}{c}\mathbf{1} \text { Bulan } \\
(\mathbf{n}=\mathbf{2 4})\end{array}$ & $\boldsymbol{P}$ \\
\hline Perilaku MP-ASI $(\%)$ & $60,0 \pm 8,24^{\mathrm{b}}$ & $61,3 \pm 12,96^{\mathrm{a}}$ & $0,020^{\mathrm{c} *}$ & $63,3 \pm 12,04^{\mathrm{b}}$ & $0,004^{\mathrm{c}^{*}}$ \\
\hline $\mathrm{a}:$ Mean $\pm S D \quad \mathrm{~b}:$ Median $\pm S D$ & $\mathrm{c}:$ Wilcoxon test $\alpha=0,05 *:$ sangat bermakna $(p<0,05)$ &
\end{tabular}

\section{PEMBAHASAN}

\section{Karakteristik Subjek}

Karakteristik merupakan salah satu faktor pemudah yang mempengaruhi perilaku seseorang. ${ }^{17}$ Hasil penelitian menunjukkan bahwa nilai tengah usia subjek pada kelompok perlakuan termasuk golongan usia dewasa yaitu 29 tahun pada kelompok perlakuan dan 24 tahun pada kelompok kontrol. Perubahan perilaku dalam proses pendidikan orang dewasa pada umumnya lebih sulit dari pada perubahan perilaku dalam pendidikan anak. Hal tersebut dapat dipahami karena orang dewasa sudah mempunyai pengetahuan, sikap dan ketrampilan tertentu yang didapat dari pengalaman hidupnya. ${ }^{10}$

Rentang usia anak pada kelompok perlakuan dan kontrol yaitu 7 bulan sampai 19 bulan. Usia setelah 6 bulan merupakan usia transisi pemberian makanan pada bayi. Sebelum usia 6 bulan bayi hanya mendapat ASI / Susu formula, setelah usia 6 bulan bayi mendapat makanan pendamping ASI yang berbentuk semi cair, berubah menjadi lunak pada usia 9 - 11 bulan dan padat pada usia setelah 12 bulan. ${ }^{18}$ Perlu diberikan informasi mengenai pemberian MP-ASI yang tepat untuk ibu dari anak usia setelah 6 bulan sampai sebelum 24 bulan. ${ }^{19}$

Nilai tengah pendidikan subjek pada kelompok perlakuan maupun kelompok kontrol sama yaitu 9 tahun atau setara dengan SMP. Seluruh subjek tidak bekerja hanya sebagai ibu rumah tangga. Pendidikan gizi yang tepat diberikan adalah dengan cara belajar pemahaman melalui bahasa yang mudah dipahami dan bisa dipelajari di rumah. ${ }^{11}$ Tidak ada perbedaan secara statistik karakteristik antara subjek pada kelompok perlakuan dan kontrol $(p>0,05)$. Homogenitas karakteristik antara kedua kelompok, menjadikan karakteristik subjek dapat dikendalikan sehingga tidak mempengaruhi hasil penelitian.

\section{Pengaruh Pendidikan Gizi Menggunakan Modul Terhadap Peningkatan Perilaku Makanan Pendamping ASI (MP-ASI)}

Sebagian besar subjek $(91,67 \%)$ pada kelompok perlakuan dan seluruh subjek pada kelompok kontrol telah memberikan MP-ASI lebih awal yaitu sebelum usia 6 bulan. Air Susu Ibu (ASI) masih diberikan pada anak sampai saat penelitian dilaksanakan, hanya $8,3 \%$ subjek pada kelompok perlakuan dan $16,7 \%$ subjek pada kelompok kontrol yang tidak memberikan ASI. Data di Puskesmas Bangetayu pada bulan September tahun 2012 juga menunjukkan bahwa sebagian besar ibu yaitu 95\% telah memberikan MP-ASI pada anaknya sebelum usia 6 bulan. ${ }^{9}$

Persentase pemberian MP-ASI dini pada penelitian ini lebih besar bila dibandingkan persentase pemberian makanan pralekteal pada anak usia 0 - 5 bulan di Jawa Tengah $(43,2 \%)$ dan di Indonesia $(44,7 \%) .{ }^{5}$ Pemberian MP-ASI pada anak sebelum usia 6 bulan masih terlalu dini, tidak sesuai rekomendasi WHO. WHO menyatakan bahwa pemberian MP-ASI dimulai sejak bayi berusia 6 bulan sampai 24 bulan, dan meneruskan pemberian ASI sampai anak berusia 24 bulan atau lebih. ${ }^{20}$

Hasil penelitian menunjukkan bahwa nilai tengah skor awal perilaku MP-ASI pada kelompok perlakuan maupun kelompok kontrol termasuk rendah $\leq 50 \%$. Tidak ada perbedaan bermakna $(p>0,05)$ nilai tengah skor awal perilaku MP-ASI antara kelompok perlakuan dan kelompok kontrol. Ibu sebagai seseorang yang berhak menentukan makanan anak dan cara memberikannya. ${ }^{21}$ Sebagian besar subjek pada kelompok perlakuan dan kontrol yaitu 81,25\% merupakan ibu yang baru mempunyai 1 anak, sehingga pengalaman dalam memberikan MP-ASI masih sedikit.

Perilaku dapat dipengaruhi faktor pemudah, pemungkin dan faktor penguat. ${ }^{17}$ Ibu yang memiliki pengetahuan dan pengalaman yang kurang mengenai MP-ASI akan merasa kurang yakin bahwa dengan pemberian MP-ASI tidak akan mencukupi kebutuhan bayi. Berdasar hasil penelitian di Tapanuli, menunjukkan bahwa faktor yang mempengaruhi perilaku MP-ASI adalah faktor pemudah yaitu sikap, dan faktor penguat yaitu dukungan keluarga dan kebiasaan memberikan MP-ASI di masyarakat. ${ }^{22}$

Hasil penelitian di Beijing, Cina mengemukakan bahwa faktor yang berhubungan dengan pemberian MP-ASI dini adalah tingkat pendidikan ibu, pekerjaan ibu dan niat awal ibu untuk menyusui. ${ }^{23}$ Rerata pendidikan subjek yang hanya SMP, pengetahuan dan sikap awal yang tidak baik, rendahnya sikap keluarga dan informasi mengenai MP-ASI dari media lain mungkin merupakan faktor rendahnya perilaku awal mengenai MP-ASI pada penelitian ini.

Deskripsi persentase jawaban perilaku MP-ASI menunjukkan bahwa masih terdapat perilaku MP-ASI saat post-test yang masih rendah $\leq 50 \%$ pada kelompok perlakuan maupun kontrol. Item yang masih rendah 
tersebut adalah persiapan sebelum memberikan MPASI dan macam MP-ASI yang diberikan.

Cara pemberian makanan pendamping ASI menurut Depkes RI (2006) yang sesuai dengan standar kesehatan adalah mencuci tangan sebelum makan dan sesudah makan, mencuci bahan makanan yang akan diolah, serta mencuci peralatan masak dan peralatan makan anak sebelum digunakan. Belum meratanya fasilitas air bersih di wilayah kerja puskesmas Bangetayu, membuat ibu kesulitan mempersiapkan MP-ASI sesuai standar kesehatan. ${ }^{20}$

Macam atau jenis MP-ASI berdasar rekomendasi WHO, adalah terdapatnya makanan pokok, lauk hewani, lauk nabati, sayur, buah, susu dan minyak. Jarang ibu yang memberikan lauk hewani, buah dan minyak kepada anak dibawah usia 2 tahun. ${ }^{18}$ Alasan mereka karena lauk hewani dan buah merupakan makanan yang mahal, sedangkan minyak dapat menyebabkan batuk. Daftar makanan penukar khususnya sumber protein hewani dengan harga terjangkau belum ada dalam modul MP-ASI, sehingga perlu ditambahkan.

Pendidikan gizi menggunakan modul MP-ASI secara statistik bermakna $(p<0,05)$ meningkatkan nilai tengah skor perilaku MP-ASI subjek pada kelompok perlakuan setelah diberi perlakuan. Nilai tengah skor post-test perilaku MP-ASI juga meningkat pada kelompok kontrol, hanya saja peningkatannya secara statistik tidak bermakna $(p>0,05)$. Perubahan nilai tengah skor perilaku MP-ASI pada kelompok perlakuan $10 \%$ lebih tinggi daripada kelompok kontrol $5 \%$.

Ada beberapa penelitian terdahulu yang mendukung hasil penelitian ini. Penelitian di Haryana, India menemukan bahwa terjadi perubahan bermakna perilaku pemberian MP-ASI pada ibu yang mendapat konseling gizi lebih baik daripada ibu yang tidak mendapat konseling gizi. ${ }^{24}$ Penelitian di Lahore, Pakistan juga mengemukakan bahwa terjadi peningkatan perilaku pemberian MP-ASI 29\% pada ibu yang mendapat konseling MP-ASI dari tenaga kesehatan daripada yang tidak mendapat konseling $4 \% .^{25}$

Promosi mengenai pemberian MP-ASI yang benar pada ibu bayi usia $6-24$ bulan perlu dilaksanakan guna mendukung perilaku pemberian MP-ASI. ${ }^{8}$ Perubahan perilaku didasari dengan adanya perubahan atau penambahan pengetahuan, sikap, atau ketrampilannya. ${ }^{26}$ Pemberian pendidikan gizi menggunakan modul MP-ASI dengan metode diskusi dan demonstrasi dapat meningkatan pengetahuan dan sikap pada kelompok perlakuan. Modul MP-ASI yang mudah dipahami dan bisa dipelajari di rumah dapat digunakan sebagai panduan perilaku pemberian MPASI subjek setelah pelatihan.
Peningkatan nilai tengah skor perilaku pada kelompok kontrol dapat terjadi karena adanya program air bersih pada saat penelitian dilaksanakan. Adanya program air bersih pada kelompok kontrol maupun kelompok perlakuan, memudahkan ibu untuk menyiapkan pemberian MP-ASI dengan baik.

\section{Retensi Perilaku MP-ASI pada Kelompok Perlakuan}

Nilai tengah skor perilaku MP-ASI mengalami peningkatan pada 2 minggu dan 1 bulan setelah diberi pendidikan gizi menggunakan modul MP-ASI. Peningkatan skor perilaku MP-ASI pada 2 minggu maupun 1 bulan setelah perlakuan secara statistik bermakna $(p<0,05)$. Hasil penelitian juga menunjukkan bahwa terjadi peningkatan retensi ketrampilan kader gizi dalam posyandu 2 bulan setelah mendapat pelatihan dengan metode belajar berdasarkan masalah. ${ }^{27}$

Peningkatan retensi perilaku MP-ASI berbeda dengan penurunan retensi pengetahuan dan sikap pada 2 minggu dan 1 bulan setelah pelatihan. Alur yang menyatakan bahwa proses pendidikan dapat merubah pengetahuan, yang akan mempengaruhi perubahan sikap, dan perubahan sikap akan berpengaruh pada perubahan perilaku tidak selamanya linear. ${ }^{28}$ Faktor pemungkin seperti paparan informasi, ketersediaan sarana dan prasarana juga dapat mempengaruhi perilaku. Reinforcing atau penguatan yang positif dapat mempertahankan perilaku yang baik. ${ }^{29}$ Perilaku yang baik bisa terjadi dengan adanya dukungan faktor penguat yaitu sikap keluarga dan dukungan tenaga kesehatan.

\section{Keterbatasan Penelitian}

Kondisi pelatihan yang kurang kondusif juga menjadi keterbatasan penelitian. Peserta pelatihan modul MP-ASI yang merupakan ibu dari anak usia 620 bulan kurang bisa fokus saat pelatihan karena ada beberapa anak yang menangis. Paparan informasi MPASI dari luar penelitian tidak dapat dikendalikan. Adanya pengaruh dari luar penelitian seperti informasi dari media massa dan sumber lain dapat mempengaruhi pengetahuan, sikap dan perilaku subjek pada 2 minggu dan 1 bulan setelah pelatihan. Perilaku pemberian jenis MP-ASI pada kelompok perlakuan tidak banyak berubah setelah mendapat pelatihan MP-ASI. Perlu penambahan daftar bahan makanan penukar dalam modul MP-ASI, sehingga ibu bisa mengetahui berbagai jenis makanan terutama lauk hewani dengan harga terjangkau untuk MP-ASI.

Waktu penelitian yang hanya 1 bulan belum bisa mengetahui perubahan waktu pemberian MP-ASI dini. Penelitian lebih lanjut dapat dilaksanakan dengan waktu yang lebih lama, sehingga bisa diketahui perubahan perilaku waktu pemberian MP-ASI dini. 
Perlu diadakan pelatihan modul MP-ASI untuk kader sebagai ujung tombak di masyarakat. Diharapkan kader bisa memberikan pelatihan modul MP-ASI secara rutin setiap bulan kepada ibu, pengasuh atau nenek.

\section{SIMPULAN}

Pendidikan gizi menggunakan modul MP-ASI berperan dalam meningkatkan perilaku ibu mengenai pemberian MP-ASI pada kelompok perlakuan, dan perubahan skornya lebih tinggi dibanding kelompok kontrol. Retensi perilaku mengalami peningkatan bermakna pada 2 minggu dan 1 bulan setelah perlakuan.

\section{SARAN}

Bagi pemerintah, terutama petugas gizi dapat menggunakan modul MP-ASI sebagai acuan pelatihan atau penyuluhan guna meningkatkan perilaku MP-ASI. Pendidikan gizi menggunakan modul MP-ASI perlu dilaksanakan rutin setiap bulan sebagai penyegaran. Penelitian lebih lanjut dapat dilakukan untuk melihat pengaruh pendidikan gizi menggunakan modul MPASI pada peningkatan perilaku ibu atau pengasuh dari anak usia dibawah dua tahun.

\section{DAFTAR PUSTAKA}

1. USAID. The Demand for Locally Manufactured Complementary Food Products Among Palestinian Caregivers on The USAID Micronutrient and Child Blindness Project; 2009.

2. Gareth J, Stekette RW, Black RE, Bhutta Za, Morris SS. How many child death can we prevent this year?; 2003. Lancet: $362: 65-71$.

3. Soenardi Tuti. Gizi Seimbang untuk Anak dan Balita dalam Hidup Sehat Gizi Seimbang dalam Siklus Kehidupan Manusia. Jakarta: Gramedia; 2006.

4. Dini L, Tatang S F, Sunawang. Program ASI Eksklusif dan MP ASI. Kumpulan Makalah Diskusi Pakar Gizi tentang ASI , MP-ASI , Antropometri dan BBLR; 2007.

5. Riskesdas. Riset Kesehatan Dasar. Badan Penelitian dan Pengembangan Kesehatan Kementrian Kesehatan Republik Indonesia. Jakarta; 2010.

6. Dinkes Kota Semarang. Profil Kesehatan Kota Semarang tahun 2011. Semarang; 2012.

7. Setyo P. Yuwono S, Heny H. Laporan Penelitian Pendekatan Intervention Mapping Aproach (IMA) pada Anak di Wilayah Kerja Puskesmas Bangetayu. Jurusan Gizi Poltekkes Kemenkes Semarang. Semarang ; 2011.
8. Aggarwal Anju et al. Complementary feeding reasons for inappropriateness In timing, quantity and consistency; 2008. Indian J Pediatric: 75 (1) : 49-53.

9. Puskesmas Bangetayu. Laporan Puskesmas Bangetayu Bulan September 2012. Puskesmas Bangetayu. Semarang; 2012.

10. Notoatmodjo S. Pendidikan dan Praktek Kesehatan. PT. Rineka Cipta. Jakarta; 2007.

11. Asikin, M. Teori Belajar. Semarang: IKIP Semarang Press; 2005.

12. Notoatmodjo S. Metodologi Penelitian Kesehatan. Rineka Cipta. Jakarta : p. 102; 2002.

13. Madiyono B, Moeslichan S, Sastroasmoro S, Budiman I, Purwanto HS.Perkiraan Besar Sampel. Dasar - Dasar Metodologi Penelitian Klinis Edisi Ke-2. Sudigdo Sastroamoro, Sofyan Ismael (penyunting). Jakarta: Sagung Seto; 2010. p.268-9.

14. Khomsan A. Teknik Pengukuran Pengetahuan. Bogor: Institut Pertanian Bogor; 2000. p.30-5.

15. Arikunto, S. Prosedur Penelitian Suatu Pendekatan Praktis. Rineka Cipta. Jakarta; 2006.

16. Ghozali I. Analisis Multivariate dengan Program SPSS. Badan Penerbit Universitas Diponegoro. Semarang; 2004.

17. Green LW,et all. Health Education Planning a Diagnostic Approach. USA: Mayfield Publishing Company: p.71; 1980.

18. PAHO/WHO. 2003. Guiding Principles for Complementary Feeding of the Breastfeed Child. PAHO, WHO. Washington, DC.

19. De Pee S, et al. Breastfeeding and Complementary Feeding Practices in Indonesia. Nutrition \& Health Surveillance System Annual Report 2002. Helen Keller Worldwide. Jakarta; 2002.

20. Depkes RI. Pedoman Umum Pemberian Makanan Pendamping Air Susu Ibu (MP-ASI) lokal tahun 2006. Jakarta; 2006.

21. Mushapi LF et al. Infant-Feeding Practices of Mothers and the Nutritional Status of Infants in the Vhembe District of Limpopo Province; 2008. S Afr J Clin Nutr 2008;21(2):36-41.

22. Padang A. Analisa Faktor - Faktor yang Mempengaruhi Ibu dalam Memberikan MP-ASI Dini di Kecamatan Pandan Kabupaten Tapanuli Tengah Tahun 2007. Tesis. Program Pascasarjana Universitas Sumatra Utara. Medan; 2008.

23. Liubai Li et all. Feeding practice of infants and their correlates in urban areas of Beijing, China; 2003. Pediatrics International 2003;45: 400-406.

24. Bhandari et al. An Educational Intervention to Promote Appropriate Complementary Feeding Practices and Physical Growth in Infants and Young Children in Rural Haryana, India; 2004. The Journal of Nutrition;134: 2342-2348. 
25. Zaman S, Rifat N. Ashraf, and José M. Training in Complementary Feeding Counselling of Healthcare Workers and Its Influence on Maternal Behaviors and Child Growth: A Cluster randomized Controlled Trial in Lahore, Pakistan. Bangladesh; 2008. Journal Health Popular Nutrition: 2008 Jun;26(2):210-222.

26. Notoatmodjo S. Pendidikan dan Praktik Kesehatan. PT. Rineka Cipta. Jakarta; 2003.

27. Sukiarko E. Pengaruh Pelatihan dengan Metode Belajar Berdasarkan Masalah terhadap Pengetahuan dan Keterampilan Kader Gizi dalam Kegiatan Posyandu: Studi di Kecamatan Tempuran Kabupaten Magelang. Tesis. Program Pascasarjana Universitas Diponegoro. Semarang; 2007.

28. Elder J P, Geller E S, Hovell M F, Mayor J A. Motivating Health Behavior. Canada; 1994. Delmar Publishers Inc: p.43-7.

29. Morris, Edward K., Nathaniel G Smith and Deborah E. Altus. 2005. B. F. Skinner's Contributions to Applied Behavior Analysis. PMCID: PMC2755377. ABAI.

30. Aboud FE, et all. A Responsive Feeding Intervention Increases Children's Self-Feeding and Maternal Responsiveness but Not Weight Gain. Bangladesh. The Journal of Nutrition; 2009. 